\title{
MENDIDIK DAN MENGAJARKAN ANAK UNTUK MENGENAL ALLAH PADA USIA DINI DENGAN METODE STORY TELLING DI TK AL-HIDAYAH PAMULANG,TANGERANG SELATAN
}

\author{
Derita Qurbani*, Bulan Oktrima, Asridah Warni Tanjung \\ Dosen Fakultas Ekonomi Universitas Pamulang \\ Email*: deritaqurbani@gmail.com
}

\begin{abstract}
ABSTRAK
Pengabdian ini berjudul Mengajarkan anak untuk mengenal Allah pada usia dini dengan metode story telling di Tk Al-hidayah Pamulang,Tangerang Selatan.

Tujuan pengabdian ini adalah untuk Mengetahui Lingkup Pendidikan Anak Usia Dini Berdasarkan Pendekatan Kebijakan dan Pendekatan Analisis Teori dan Membantu memberikan arahan menjadi bagaimana cara ber komunikasi yang baik terhadap anak, dan mengenalkan pendalaman ilmu agama terhadap anak guna membantu anak mengendalikan emosinya.

Metode yang digunakan adalah Metode pelaksanaan pengabdian ini dilakukan dalam beberapa kegiatan yaitu tahap survei yaitu sosialisasi dilakukan dengan menyusun berbagai hal yang akan disampaikan pada saat kegiatan pengabdian yang akan dilakukan yang meliputi: penyusunan materi yang akan diberikan, penyusunan jadwal pemberian materi, pembagian tugas tim pengabdian dan survei ke lokasi pengabdian. Tahap sosialisasi yaitu sebelum kegiatan pengabdian dilaksanakan terlebih dahulu dilakukan tahap sosialisasi yaitu melakukan silaturahmi dengan ketua yayasan, menyampaikan maksud dan tujuan pengabdian ini. Pada tahap ini juga dilakukan jalinan kerjasama dan menentukan jadwal kegiatan pengabdian. Tim pelaksana kegiatan pengabdian pada masyarakat adalah dosen Fakultas Ekonomi jurusan manajemen sebanyak 11 orang dalam bentuk penyampaian materi Mengajarkan anak untuk mengenal Allah pada usia dini dengan metode story telling.

Kesimpulan dari pengabdian ini adalah Peserta kurang mengerti apa itu Mengajarkan anak untuk mengenal Allah pada usia dini dengan metode story telling dan hasil dari mengenalkan Allah pada usia dini terhadap pembentukan karakter anak.
\end{abstract}

Kata Kunci: Mengenalkan Allah, Metode story telling 


\section{PENDAHULUAN}

Mencetak generasi unggul dan "sukses hidup" di tengah persaingan global dapat dilakukan dengan jalan menyelenggarakan pendidikan yang memberikan kesempatan seluas-luasnya kepada anak didik untuk tumbuh dan berkembang sesuai dengan potensi, bakat, minat dan kesanggupannya. Menyelenggarakan pendidikan yang membebaskan anak dari tindak kekerasan.Menyelenggarakan pendidikan yang memperlakukan anak dengan ramah. Menyelenggarakan pendidikan yang memanusiakan anak.Menyelenggarakan pendidikan yang memenuhi hak-hak anak. Hal tersebut akan terwujud jika pendidikan yang demikian dilakukan sejak anak usia dini.

Pada awalnya, hanya lembaga pendidikan Taman Kanak-kanak yang mengalami perkembangan pesat di Indonesia hingga penghujun 1999.Bahkan, dulu lembaga ini hanya berkembang di daerah-daerah perkotaaan.Tetapi, sekarang pertumbuhan lembaga Taman Kanak-kanak telah merambah hingga ke sudut-sudut pedesaan.Sementara itu, lembaga PAUD yang lain, seperti TPA dan KB di saat TK/RA berkembang pesat belum ada tanda-tanda kemunculan waktu itu. Bahkan, di daerah perkotaan pun masih sangat jarang.Jangankan di daerah pedesaan, di kotakota besar masih jarang dijumpai lembaga PAUD yang menyelenggarakan TPA dan KB.

Tetapi, mulai tahun 2003 hingga penghujung 2008, tepatnya semenjak disahkannya UU No. 20 tahun 2003 lembaga PAUD, mulai dari TK/RA, KB dan TPA mulai berkembang dengan pesat. Hingga saat ini, penyebaran dan pertumbuhan lembaga PAUD tidak hanya menjamur di daerah-daerah perkotaan saja, tetapi telah masuk ke sudut-sudut perkampungan.

Pendidikan anak usia dini merupakan program pendidikan yang dicanangkan pemerintah untuk memenuhi kebutuhan pertumbuhan dan perkembangan anak, seperti yang tercantum pada UU Nomor 20 tahun 2003 pasal 1 ayat 14. Pendidikan anak usia dini adalah suatu upaya pembinaan yang ditujukan kepada anak sejak lahir sampai dengan usia enam tahun yang dilakukan melalui pemberian rangsangan pendidikan untuk membantu pertumbuhan dan perkembangan jasmani rohani anak agar anak memiliki kesiapan dalam memasuki pendidikan lebih lanjut. (UU Sisdiknas, 2003: 2 dalam pdf www.inherent-dikti.net) Pendidikan anak usia dini menjadi pilar utama dalam mengembangkan kualitas sumber daya manusia. Pendidikan sebagai pengubahan sikap dan tingkah laku seseorang atau kelompok orang dalam hal mendewasakan manusia melalui upaya pengajaran dan pelatihan. Bahasa merupakan modal utama dalam upaya mendapatkan informasi dan berkomunikasi dalam kehidupan. Tanpa adanya bekal tersebut, kita tidak akan memperoleh informasi dan tidak akan dapat berkomunikasi dengan yang 
semestinya. Tujuan utama bahasa adalah untuk mendapatkan informasi dan paham akan berkomunikasi. Salah satu kegiatan yang bisa mengembangkan kecerdasan bahasa anak adalah Storytelling. Dimana dalam kegiatan ini suatu proses kreatif anak-anak yang dalam perkembangannya, senantiasa mengaktifkan bukan hanya aspek intelektual saja tetapi juga aspek kepekaan, kehalusan budi, emosi, seni, daya berfantasi, dan imajinasi anak yang tidak hanya mengutamakan kemampuan otak kiri tetapi juga otak kanan. Berbicara mengenai metode ini dapat dilihat bahwa secara umum semua anak-anak senang mendengarkan cerita pada saat kegiatan pembelajaran berlangsung didalam kelas. Menurut Asfandiyar (2007:2) Storytelling merupakan sebuah seni bercerita yang dapat digunakan sebagai sarana untuk menanamkan nilainilai pada anak yang dilakukan tanpa perlu menggurui sang anak. Dalam kegiatan storytelling, proses bercerita menjadi sangat penting karena dari proses inilah nilai atau pesan dari cerita tersebut dapat sampai pada anak. Pada saat proses storytelling berlangsung terjadi sebuah penyerapan pengetahuan yang disampaikan storyteller kepada audience. Proses inilah yang menjadi pengalaman seorang anak dan menjadi tugas gurulah untuk menampilkan kesan menyenangkan pada saat bercerita. Storytelling dengan media buku, dapat digunakan Guru TK untuk memberikan pengalaman yang menyenangkan terhadap buku. Di masa sekarang, bercerita memang merupakan hal yang jarang dilakukan. Peran dan fungsinya sudah banyak tergantikan oleh tayangan televisi dan bermain game di komputer. Terlepas dari semua itu, cerita memiliki kekuatan, fungsi dan manfaat sebagai media komunikasi, sekaligus metode dalam membangun kepribadian anak. Dengan adanya kegiatan storytelling tentu dapat memberikan pengaruh pada anak. Pengaruh tersebut dapat berupa pertumbuhan minat baca, hal inilah yang menarik untuk diteliti. Kecerdasan bahasa dan minat membaca pada anak usia di TK saat ini sudah sangat maju. Permainan Storytelling bertujuan untuk memperkenalkan anak-anak agar lebih mencairkan suasana dalam merangsang minat baca di usia dini. Menurut Joseph Frank (1995, dalam Asfandiyar, 2007: 6) storytelling merupakan salah satu cara yang efektif untuk mengembangkan aspekaspek kognitif (pengetahuan), afektif (perasaan), sosial, dan aspek konatif (penghayatan) anak-anak. Di TK sudah menerapkan kegiatan storytelling sejak tahun 2000an, akan tetapi kita belum mengetahui pengaruhnya secara pasti dalam menumbuhkan minat baca dan bahasa anak

Sebelum dibicarakan tentang pendidikannya terlebih dahulu akan dibahas tentang anak usia dini. adapun yang dimaksud dengan anak usia dini adalah sebagai berikut:[1] Anak usia dini adalah kelompok manusia yang berusia 0-6 tahun (di Indonesia berdasrkan Undang-undang Nomor 20 Tahun 2003 tentang Sistem Pendidikan Nasional), adapun berdasrkan para pakar pendidikan anak, yaitu 
kelompok manusia yang berusia 9-8 tahun. Anak usia dini adalah kelompok anak yang berada dalam proses pertumbuhan dan perkembangan yang bersifat unik, dalam arti memiliki pola pertumbuhan dan perkembangan (koordinasi motorik halus dan kasar), intelegensi (daya pikir, daya cipta, kecerdasan emosi, dan kecerdasan spiritual), sosial emosional (sikap dan perilaku serta agama), bahasa dan komunikasi yang khusus sesuai dengan tingkat pertumbuhan dan perkembangan anak. Berdasarkan keunikan dalam pertumbuhan dan perkembangannya, anak usia dini terbagi dalam tiga tahapan, yaitu (a) masa bayi lahir sampai 12 bulan, (b) masa toddler (batita) usia 1-3 tahun, (c) masa prasekolah usia 3-6 tahun, (d) masa kelas awal SD 6-8 tahun. Pertumbuhan dan perkembangan anak usia dini perlu diarahkan pada peletakan dasar-dasar yang tepat bagi pertumbuhan dan perkembangan manusia seutuhnya, yaitu pertumbuhan dan perkembangan fisik, daya pikir, daya cipta, sosial emosional, bahasa dan komunikasi yang seimbang sebagai dasar pembentukan pribadi yang utuh.

Pendidikan bagi anak usia dini adalah pemberian upaya untuk menstimulasi, membimbing, mengasuh dan pemberian kegiatan pembelajaran yang akan menghasilkan kemampuan dan keterampilan anak. Pendidikan bagi anak usia dini merupakan sebuah pendidikan yang dilakukan pada anak yang baru lahir sampai dengan delapan tahun. Pendidikan pada tahap ini memfokuskan pada physical, intelligence, emotional, social education.

Sesuai dengan keunikan dan pertumbuhan anak usia dini maka penyelenggaraan pendidikan bagi anak usia dini disesuaikan dengan tahap-tahap perkembangan yang dilalui oleh anak usia dini. Upaya PAUD bukan hanya dari sisi pendidikan saja, tetapi termasuk upaya pemberian gizi dan kesehatan anak sehingga dalam pelaksanaan PAUD dilakukan secara terpadu dan komprehensif

Pendidikan anak usia dini pada dasarnya meliputi seluruh upaya dan tindakan yang dilakukan oleh pendidik dan orang tua dalam proses perawatan, pengasuhan, dan pendidikan pada anak dengan menciptakan aura dan lingkungan dimana anak dapat mengeksplorasi pengalaman yang memberikan kesempatan kepadanya untuk mengetahui dan memahami pengalaman belajar yang diperolehnya dari lingkungan, melalui cara mengamati, meniru, dan bereksperimen yang berlangsung secara berulang-ulang dan melibatkan seluruh potensi dan kecerdasan anak. Oleh kerena anak merupakan pribadi yang unik dan melewati berbagai tahap perkembangan kepribadian, maka lingkungan yang diupayakan oleh pendidik dan orangtua yang dapat memberikan kesempatan pada anak untuk mengeksplorasi berbagai pengalaman dengan berbagai suasana, hendaklah memperhatikan keunikan anak-anak dan disesuaikan dengan tahap perkembangan kepribadian anak.Contoh : jika anak dibiasakan untuk berdoa sebelum melakukan kegiatan baik 
di rumah maupun lingkungan sekolah dengan cara yang paling mudah dimengerti anak, sedikit demi sedikit anak pasti akan terbiasa untuk berdoa walaupun tidak di damping oleh orang tua ataupun guru mereka.

Pendidikan adalah proses interaksi antara pendidik dan anak didik dan atau lingkungan secara sadar, teratur, terencana dan sistematis guna membantu pengembangan potensi anak didik secara maksimal. Pengertian ini dianggap lebih lengkap dan memadai daripada pengertian-pengertian tentang pendidikan yang dikemukakan oleh banyak ahli di bidang pendidikan.[4]

Setelah dikatakan Anak Usia Dini, berikut di paparkan tentang Pendidikan Anak Usia Dini ( PAUD ). PAUD adalah suatu proses pembinaan tumbuh kembang anak usia lahir hingga enam tahun secara menyuluruh, yang mencakup aspek fisik dan non-fisik, dengan memberikan rangsangan bagi perkembangan jasmani, rohani (moral dan spiritual ), motorik, akal pikir, emosional, dan sosial yang tepat agar anak dapat tumbuh dan berkembang secara optimal. Adapun upaya yang dilakukan mencakup stimulasi intelektual, pemeliharaan kesehatan, pemberian nutrisi, dan penyediaan kesempatan yang luas untuk mengeksplorasi dan belajar secara aktif.

Dengan demikian, PAUD dapat di deskripsikan sebagai berikut :Pertama, Pendidikan Anak Usia Dini (PAUD) adalah pemberian upaya untuk menstimulasi, membimbing, mengasuh, dan pemberian kegiatan pembelajaran yang akan menghasilkan kemampuan dan keterampilan pada anak. Kedua, Pendidikan Anak Usia Dini (PAUD) merupakan salah satu bentuk penyelenggaraan yang menitikberatkan pada peletakan dasar kearah pertumbuhan dan perkembangan fisik (koordinasi motorik halus dan kasar), kecerdasan (daya pikir, daya cipta, kecerdasan emosi, dan kecerdasan spiritual), sosio-emosional (sikap perilaku serta agama), bahasa dan komunikasi. Ketiga, sesuai dengan keunikan dan pertumbuhan Pendidikanan Usia Dini (PAUD) disesuaikan dengan tahap-tahap perkembangan yang dilalui oleh anak usia dini.

\section{RUMUSAN MASALAH}

Dengan mempertimbangkan latar belakang yang telah diutarakan diatas kami berinisiatif untuk membentuk pengabdian masyarakat bagi anak- anak melalui progam penyuluhan materi mendidik dan mengajarkan mengenal Allah pada usia dini dengan metode story telling Tk Al-hidayah Pamulang oleh UNPAM dan DPMP3AKB yang beralamatkan J1.Matoa I No.20 Pamulang.Tangerang Selatan. 15417. dengan bekerja sama dengan DPMP3AKB.Membekali anak-anak untuk hidup dalam lingkungan yang sehat dan beradap. 


\section{TUJUAN}

Tujuan PAUD yang ingin dicapai adalah untuk mengembangkan pengetahuan dan pemahaman orang tua dan guru serta pihak-pihak yang terkait dengan pendidikan dan perkembangan anak usia dini. secara khusus tujuan yang ingin dicapai, adalah :

1. Dapat mengidentifikasi perkembangan fisiologis anak usia dini dan mengaplikasikan hasil identifikasi tersebut dalam pengembangan fisiologis yang bersangkutan.

2. Dapat memahami perkembangan kreatifitas anak usia dini dan usaha-usaha yang terkait dengan pengembangannya.

3. Dapat memahami kecerdasan jamak dan kaitannya dengan perkembangan anak usia dini.

4. Dapat memahami arti bermain bagi perkembangan anak usia dini.

5. Dapat memahami pendekatan pembelajaran dan aplikasinya bagi pengembangan anak usia kanak-kanak.

Tujuan pendidikan anak usia dini secara umum adalah mengembangkan berbagai potensi anak sejak dini sebagai persiapan untuk hidup dan dapat menyesuaikan diri dengan lingkungannya. Secara khusus kegiatan pendidikan bertujuan agar:

1. Anak mampu melakukan ibadah, mengenal dan percaya akan ciptaan Tuhan dan mencintai sesama. Contoh : pendidik mengenalkan kepada anak didik bahwa Allah SWT menciptakan berbagai makhluk selain manusia, seperti binatang, tumbuhan, dan sebagainya yang semua itu harus kita sayangi.

2. Anak mampu mengelola keterampilan tubuh termasuk gerakan-garakan yang mengontrol gerakan tubuh, gerakan halus dan gerakan kasar, serta menerima rangsangan sensorik (panca indera). Contoh: menari, bermain bola, menulis ataupun mewarnai.

3. Anak mampu menggunakan bahasa untuk pemahaman bahasa pasif dan dapat berkomunikasi secara efektif yang bermanfaat untuk berpikir dan belajar. Contoh : ketika sudah melakukan pembahasan tema, diberikan kepada anak didik untuk bertanya atau menjawab isi tema yang telah diberikan.

4. Anak mampu berpikir logis, kritis, memberikan alasan, memecahkan masalah dan menemukan hubungan sebab akibat. Contoh : mencari pasangan gambar yang berkaitan dengan sebab akibat, lalu anak akan berusaha memecahkan masalah dan memberika alasan tersebut.

5. Anak mampu mengenal lingkungan alam, lingkungan sosial, peranan masyarakat dan menghargai keragaman sosial dan budaya serta mampu 
mengembangkan konsep diri, sikap postif terhadap belajar, kontrol diri dan rasa memiliki.

6. Anak memiliki kepekaan terhadap irama, nada, birama, berbagai bunyi, bertepuk tangan, serta menghargai hasil karya yang kreatif. Contoh : anak yang senang dan menyukai dengan musik, saat mendengar lagu maka akan segera mengikutinya, ataupun ketika diminta melanjutkan syair kedua hingga selesai, maka anak mampu melakukannya.

Selain itu, tujuan pendidikan anak usia dini adalah :

1. Untuk membentuk anak Indonesia yang berkuailtas, yaitu anak yang tumbuh dan berkembang sesuai dengan tingkat perkembangannya sehingga memiliki yang optimal di dalam memasuki pendidikan dasar serta mengarungi kehidupan di masa dewasa.

2. Untuk membantu menyiapkan anak mencapai kesiapan belajar (akademik) di sekolah.

3. Intervensi dini dengan memberikan rangsangan sehingga dapat menumbuhkan potensi-potensi yang tersembunyi (hidden potency) yaitu dimensi perkembangan anak (bahasa, intelektual, emosi, sosial, motorik, konsep diri, minat dan bakat)

4. Melakukan deteksi dini terhadap kemungkinan terjadinya gangguan dalam pertumbuhan dan perkembangan potensi-potensi yang dimiliki anak.

Beberapa fungsi pendidikan bagi anak usia dini yang harus diperhatikan, dapat

dijelaskan sebagai berikut: (1) Untuk mengembangkan seluruh kemampuan yang dimiliki anak sesuai dengan tahapan perkembangannya. Contoh : menyiapkan media pembelajaran yang banyak sesuai dengan kebutuhan dan minat anak; (2) Mengenalkan anak dengan dunia sekitar. Contoh: field tripke Taman Safari, selain dapat mengenal bermacam-macam hewan ciptaan Allah juga dapat mengenal berbagai macam tumbuhan dan hewan serta mengenal perbedaan udara panas dan dingin; (3) Mengembangkan sosialisasi anak. Contoh: bermain bersama teman, melalui bermain maka anak dapat berinteraksi dan berkomunikasi sehingga proses sosialisasi anak dapat berkembang; (4) Mengenalkan peraturan dan menanamkan disiplin pada anak. Contoh: mengikuti peraturan atau tata cara upacara bendera, dapat menanamkan peraturan dan mengenal arti penghormatan kepada pahlawan perjuangan bangsa; (5) Memberikan kesempatan pada anak untuk menikmati masa bermainnya. Contoh: bermain bebas sesuai dengan minat dan keinginan anak; (6) Memberikan stimulus kultural pada anak. 
Fungsi lainnya yang perlu diperhatikan, yakni penyiapan bahan perumusan kebijakan dibidang pendidikan anak usia dini; penyiapan bahan perumusan standar, criteria, pedoman, dan prosedur dibidang pendidikan anak usia dini; pemberian bimbingan teknis dan evaluasi dibidang pendidikan anak usia dini; pelaksanaan pemberdayaan peran serta masyarakat dibidang pendidikan anak usia dini; pelaksanaan urusan ketatausahaan Direktorat (Direktorat PAUD, 2000:6).

Rasulullah -shallallahu 'alaihi wa sallam - telah mencontohkan kepada kita agar mengenalkan Allah -subhanahu wa ta'ala- pada anak sedini mungkin. Serta mengajarkannya agar ketika ia memiliki keinginan atau membutuhkan pertolongan maka ia harus meminta kepada Allah -subhanahu wa ta'ala- setelah itu baru dikomunikasikan kepada orang tua dan yang lainnya sebagai bentuk penyempurnaan usaha. Seperti yang Beliau sampaikan kepada ibnu Abbas sewaktu ia masih kanak-kanak.

Rasulullah -shallallahu 'alaihi wa sallam- mengatakan kepada ibnu Abbas, "Wahai anakku, sesungguhnya aku akan mengajarkanmu beberapa kata ini sebagai nasihat buatmu. Jagalah hak-hak Allah, niscaya Allah pasti akan menjagamu. Jagalah dirimu dari berbuat dosa terhadap Allah, niscaya Allah akan berada di hadapanmu. Apabila engkau menginginkan sesuatu, mintalah kepada Allah. Dan apabila engkau menginginkan pertolongan, mintalah pertolongan kepada Allah. Ketahuilah bahwa apabila seluruh umat manusia berkumpul untuk memberi manfaat kepadamu, mereka tidak akan mampu melakukannya kecuali apa yang telah dituliskan oleh Allah di dalam takdirmu. Juga sebaliknya, apabila mereka berkumpul untuk mencelakai dirimu, niscaya mereka tidak akan mampu mencelakaimu sedikitpun kecuali atas kehendak Allah. Pena telah diangkat dan lembaran takdir telah kering." (HR. Tirmidzi)

Jika anak telah terbiasa meminta kepada Allah-subhanahu wa ta'alamaka ia akan menjadi pribadi yang mulia karena tidak terbiasa meminta-minta kepada manusia. Karakternya begitu kuat karena ia bersandar pada sesuatu yang Maha kuasa dan Maha perkasa.

Sekaya dan sekuat apapun orang tuanya tidak akan mampu memenuhi keinginannya yang tak terbatas. Dunia ini begitu lemah dan begitu rapuh ketika berhadapan dengan hawa nafsu manusia. Tidak ada yang mampu memenuhi keinginan dan khayalan manusia kecuali Allah -subhanahu wa ta'ala-.

Maka dari itu jangan pernah merasa sulit ketika ingin mengenalkan anak pada Allah -subhanahu wa ta'ala- terlebih melatihnya agar terbiasa berdoa. Karena Ini sangat bermanfaat untuk kehidupannya di masa mendatang dan ini benar-benar tanggung jawab kita yang pertama dan utama sebagai orang tua. 
Dengan adanya materi ini tentang pengenalan Allah pada usia dini dengan metode story telling, Para orang tua dapat mmebentuk karakter anak agar lebih bijak dan memilik pemahaman agama yang lebih baik. Oleh karena itu ,Perlu adanya dukungan dan pihak Yayasan untuk menjalankan pelatihan ini agar tersampaikan dengan maksimal

\section{METODE PELAKSANAAN}

Metode pelaksanaan pengabdian ini dilakukan dalam beberapa kegiatan yaitu tahap survei yaitu sosialisasi dilakukan dengan menyusun berbagai hal yang akan disampaikan pada saat kegiatan pengabdian yang akan dilakukan yang meliputi: penyusunan materi yang akan diberikan, penyusunan jadwal pemberian materi, pembagian tugas tim pengabdian dan survei ke lokasi pengabdian. Tahap sosialisasi yaitu sebelum kegiatan pengabdian dilaksanakan terlebih dahulu dilakukan tahap sosialisasi yaitu melakukan silaturahmi dengan ketua yayasan, menyampaikan maksud dan tujuan pengabdian ini. Pada tahap ini juga dilakukan jalinan kerjasama dan menentukan jadwal kegiatan pengabdian. Tim pelaksana kegiatan pengabdian pada masyarakat adalah dosen Fakultas Ekonomi jurusan manajemen sebanyak 11 orang. Tim pengabdian memberikan materi tentang Mendidik dan Mengajarkan anak untuk mengenal Allah pada usia dini dengan metode story telling di Tk Al-hidayah Pamulang, Tangerang Selatan dan akan memberikan pelatihan disana oleh dosen UNPAM dan bekerja sama dengan DPMP3AKB.

\section{HASIL DAN PEMBAHASAN}

Pengabdian Masyarakat (LPPM) Universitas Pamulang yang dilakukan oleh dosen-dosen program studi Manajemen telah berjalan dengan lancar dan mendapat sambutan hangat dari tempat pelaksanaan kegiatan ini yaitu di TK AlHidayah Pamulang, Tangerang Selatan .

Harapan kami dengan pengabdian ini dapat membuka wawasan masyarakat yang diperoleh adalah bertambahnya keilmuan bagi para Para Masyarakat Mendidik dan Mengajarkan anak untuk mengenal Allah pada usia dini dengan metode story telling di Tk Al-hidayah Pamulang, Tangerang Selatan dan Ilmu yang diperoleh pada Pengabdian Masyarakat kali ini diharapkan mampu memberikan semangat baru bagi kita semua, dalam menyampaikan materi dan motivasi serta berkontribusi bagi generasi muda, baik dilingkungan sekolah, kampus dan keluarga.

Harapannya dengan pengabdian ini dapat membuka wawasan dari Para Kepala Keluarga dan Ibu rumah tangga dapat mengerti dampak dari Kekerasan rumah Tangga Terhadap Psikologi Wanita dan Anak- anak, sehingga dapat 
membantu dan meningkatkan tingkat keilmuan dan keperibadian yang baik secara rohani dan jasmani sehat yang akan sangat bermanfaat dalam kehidupan mereka pada masa yang akan datang.

\section{KESIMPULAN DAN SARAN}

\section{Kesimpulan}

Peserta kurang mengerti bagaimana Mendidik dan Mengajarkan anak untuk mengenal Allah pada usia dini dengan metode story telling. Peserta juga belum mengetahui bagaimana cara Mendidik dan Mengajarkan anak untuk mengenal Allah pada usia dini dengan metode story telling.

\section{Saran}

Setelah pengabdian ini diharapkan peserta dapat memiliki hidup yang lebih sehat secara rohani dan membangun keluarga yang lebih harmonis serta dapat mempraktekanya pada kehidupan. Tim pengabdian agar terus melakukan kegiatankegiatan serupa secara berkesinambungan di masa yang akan datang

\section{DAFTAR PUSTAKA}

Arikunto, Suharsimi. 2008. Dasar-Dasar Evaluasi Pembelajaran. Jakarta: Bumi Aksara. 308 hlmn.

Kartini Kartono, 2008, Pemimpin dan kepemimpinan. Jakarta: Raja Grafindo Persada

Prijosaksono, Aribowo dan Sri Bawono.2005. The Power of Entrepreneurial Intelligence,Membangun Sikap dan Perilaku Entrepreneur Dalam Diri Anda. Elex Media Komputindo, Jakarta

Edhi Prasetyo M. Wahyuddin. 2011. Jurnal . 'Pengaruh Kepuasan Dan Motivasi Kerja Terhadap Produktivitas Kerja Karyawan Riyadi Palace Hotel Di Surakarta'. Program Pascasarjana Universitas Muhammadiyah Surakarta Jalan A. Yani, Tromol Pos 1, Pabelan, Surakarta 57102

Handoko,T.Hani. 2012. Manajemen Personalia dan Sumber Daya Manusia. Edisi Ke-2. Yogyakarta: BPFE.

L.Mathis., Robert dan John H.Jackson.Manajemen Sumber Daya Manusia. PT.Salemba 4. Jakarta. Edisi 10. 2006 
Malayu Hasibuan S. P. 2012. Manajemen Sumber Daya Manusia. Cetekan keenam belas. Jakarta. PT. Bumi Akasara.

Mangkunegara, A.A Anwar Prabu. 2009. Manajemen Sumber Daya Manusia. Bandung: PT. Remaja Rosdakarya.

Mangkunegara.,Anwar Prabu. Manajemen Sumber Daya Manusia Perusahaan. PT.Remaja Rosdakarya. Bandung. Cetakan ke-12. 2013

Marosno. 2013. Pengaruh Motivasi dan Disiplin Kerja Terhadap Kinerja Karyawan pada PT Satwiga Musiga Naga Contract. Skripsi. Tangerang Selatan.

Marwansyah. Manajemen Sumber Daya Manusia. CV Alfabeta. Bandung. 2010

Ma`ruf., Abdullah. Manajemen Dan Evaluasi Kinerja Karyawan. Swanda Presindo. Yogyakarta. 2014

Nawawi., Hadari. Perencanaan SDM (Untuk Organisasi Profit Yang Kompetitif). Gadjah Mada University Press. Cetakan ke-5. 2010

\section{DOKUMENTASI FOTO KEGIATAN}

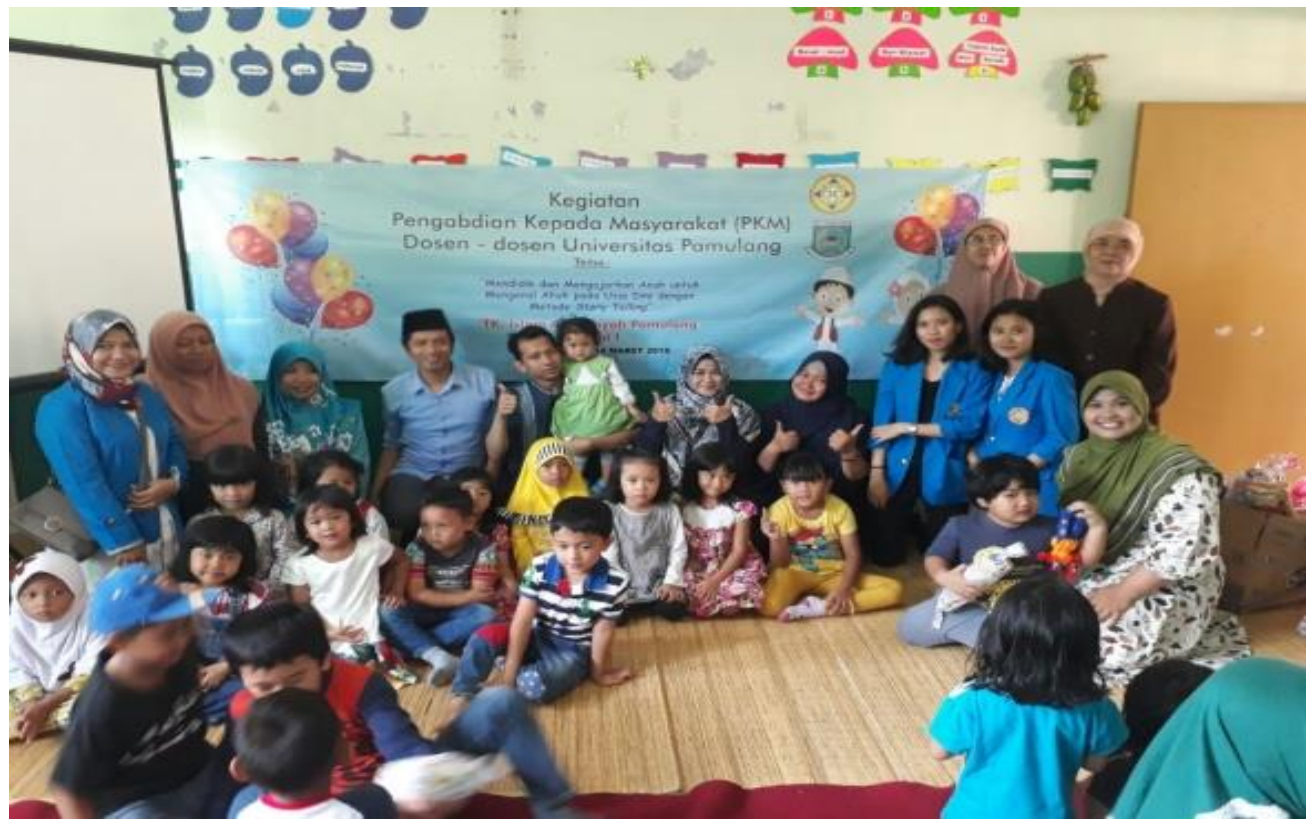



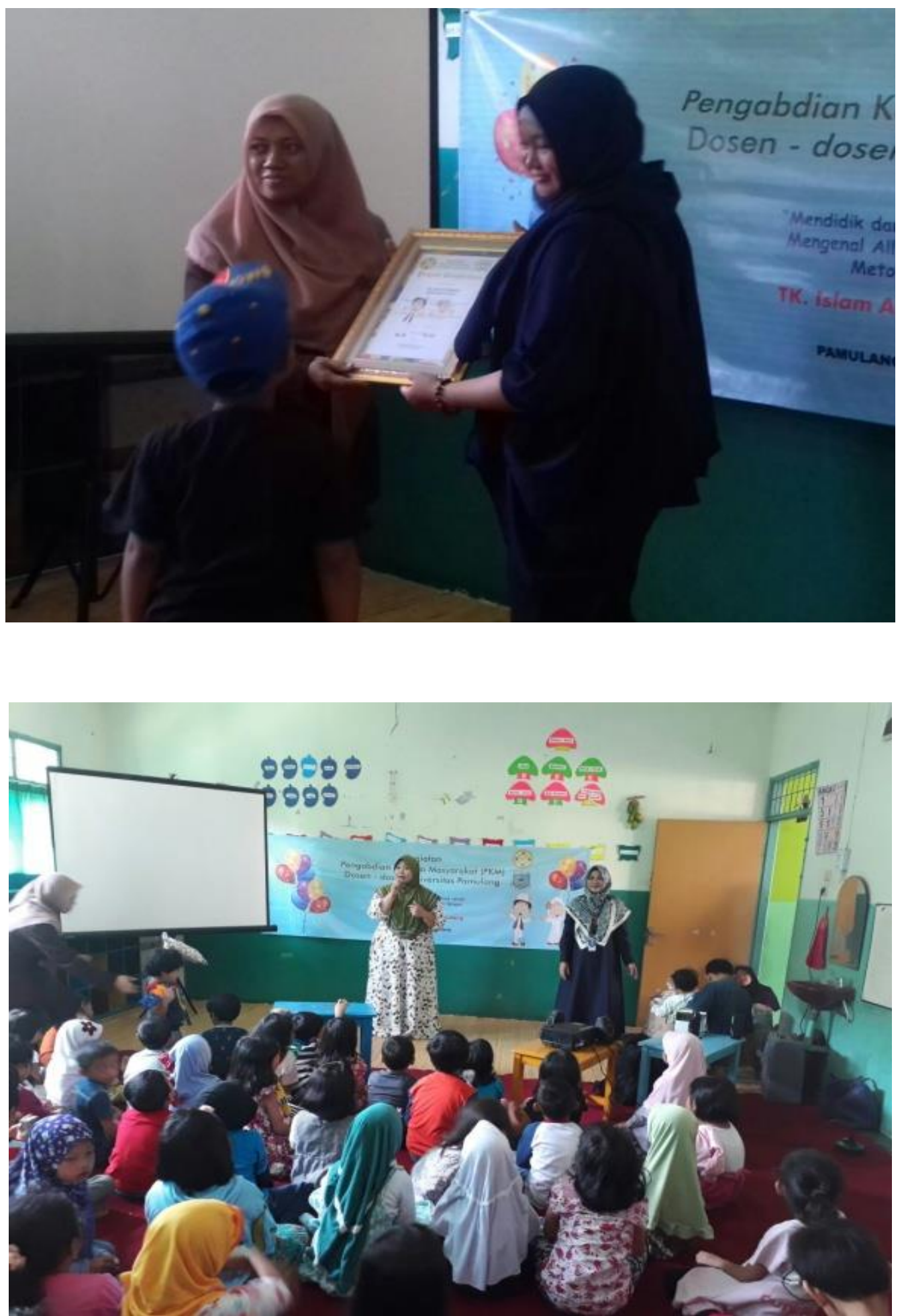